\title{
Phytochemical Screening, Antioxidant, Anti-inflammatory, and Glucose Utilization Activities of Three South African Plants Used Traditionally to Treat Diseases
}

\author{
Oyinlola O. Olaokun ${ }^{1, *}$, Nqobile M. Mkolo, M. A. Mogale ${ }^{2}$, Piet H. King ${ }^{1}$ \\ ${ }^{1}$ Department of Biology, Sefako Makgatho Health Sciences University, PO Box 139, Medunsa 0204, South Africa \\ ${ }^{2}$ Department of Biochemistry, Sefako Makgatho Health Sciences University, PO Box 139, Medunsa 0204, South Africa
}

*Corresponding author: Olaokun OO, Department of Biology, Sefako Makgatho Health Sciences University, PO Box 139, Medunsa 0204, South Africa; E-mail: oyinolaokun@ yahoo.com

Received: March 29, 2017; Accepted: July 13, 2017; Published: July 20, 2017

Copyright: @ 2017 Olaokun et al. This is an open-access article distributed under the terms of the Creative Commons Attribution License, which permits unrestricted use, distribution, and reproduction in any medium, provided the original author and source are credited.

\begin{tabular}{|c|}
\hline \\
\hline 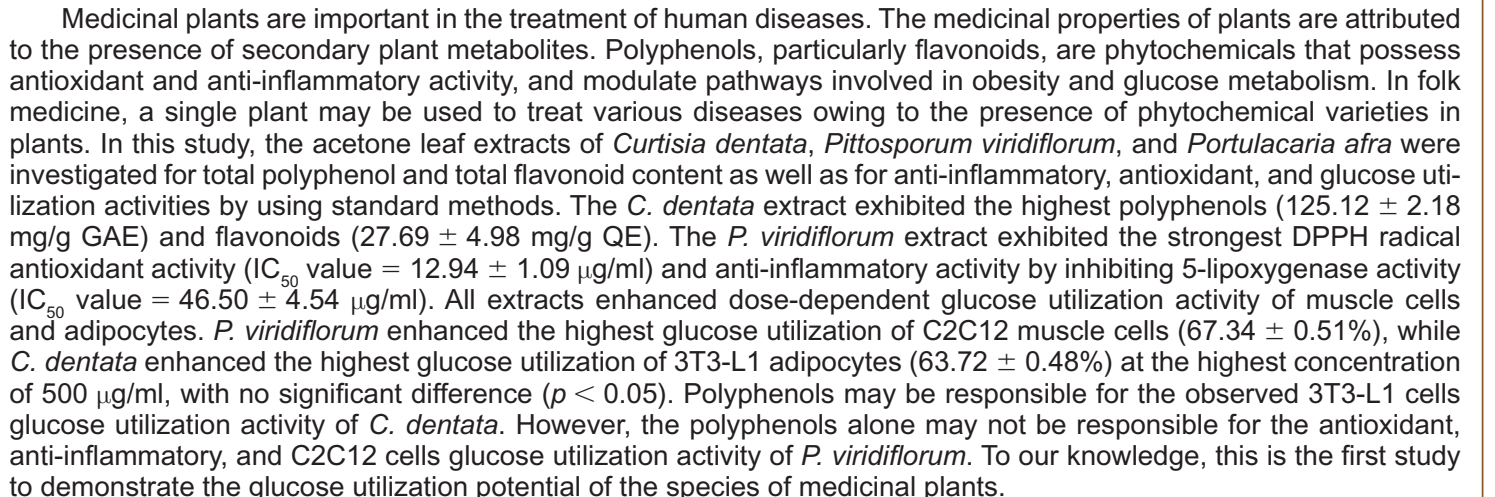 \\
\hline
\end{tabular}

Keywords: Medicinal plants; Phytochemicals; Polyphenols; Type 2 diabetes; Anti-inflammatory; Antioxidant

\section{Introduction}

Medicinal plants play an important role in the treatment of human diseases, particularly in the developing world. In this regard, the World Health Organization [1] also realized that an effective health agenda for developing countries can never be achieved by the use of conventional western medicine alone. Accordingly, WHO advised and urged developing countries to utilize their medicinal plant resources and other traditional medicine systems in order to achieve the objective of primary health care $[1,2]$. In addition, herbal medicines are used in developed countries of the world. The utilization of herbal medicine in developed countries is believed to be motivated by several factors, including the lower side effects of phytomedicines compared with modern synthetic drugs, the lower cost of phytomedicines compared with modern synthetic drugs as well as the effectiveness of some plant remedies [3].

In South Africa, similar to many other developing countries, medicinal plants and herbal formulations play important roles in the daily health care of the people [4]. The country is rich in floral biodiversity, which is a natural reservoir for the preparation of herbal medicine [5]. It is estimated that more than 4000 plant taxa are used in herbal formulations countrywide [6]. Katerere and Eloff [7] have identified many Southern African species that are used to treat diabetes, their chemistry and the pharmacological evidence for their efficacy.
The medicinal properties of plant remedies have been attributed to the presence of secondary plant metabolites including polyphenols, steroids, alkaloids, terpenoids, and glycosides [8]. Phenolic compounds, particularly flavonoids, are secondary plant metabolites that are able to regulate the pathways involved in adiposity and obesity [9]. They also possess antioxidant [10], anti-inflammatory, and blood glucose lowering properties [11]. Therefore, plants rich in such phytochemicals could be used in the treatment of medical conditions associated with chronic hyperglycemia, oxidative stress, and obesity-induced inflammation, such as type 2 diabetes mellitus.

Type 2 diabetes mellitus is a non-insulin-dependent chronic hyperglycemia resulting from insulin resistance in responsive cells in association with pancreatic $\beta$-cell dysfunction [4]. It is a genetic disorder, but overweight and obesity are factors responsible for the development of the disease [12]. Obesity is a condition of excessive adipose tissues accumulation that is characterized by the over-production of free fatty acids, adipokines, and activation of inflammatory signaling pathways $[13,14]$. Studies have demonstrated that chronic hyperglycemia can induce oxidative stress, provoked by excessive generation of free radicals or by the impairment of endogenous antioxidant defense, and has been implicated in the development of diabetic complication [15]. Therefore, a crude plant extract or an isolated and purified phytochemical agent possessing blood glucose lowering effects, in addition to antioxidant and anti-inflammatory activity, may be an ideal treatment for type 2 diabetes mellitus.

In South Africa, the stem bark extracts of the medicinal plants' species Curtisia dentata and Pittosporum viridiflorum, as well as the 
Citation: Olaokun OO, Mkolo NM, Mogale MA, King PH (2017) Phytochemical Screening, Antioxidant, Anti-inflammatory and Glucose Utilization Activities of Three South African Plants Used Traditionally to Treat Diseases. Biol Med (Aligarh) 9: 412. doi: 10.4172/0974-8369.1000412

Page 2 of 7

\begin{tabular}{|c|c|c|c|}
\hline $\begin{array}{l}\text { Plant species } \\
\text { (family) }\end{array}$ & Part used & Uses & Reference \\
\hline $\begin{array}{l}\text { Curtisia dentata } \\
\text { (Burm.f.) C.A. } \\
\text { Sm(Cornaceae) }\end{array}$ & Stem bark & $\begin{array}{c}\text { Obesity, stomach } \\
\text { ailments, fever, diarrhea, } \\
\text { cancer, hypertension, } \\
\text { constipation, aphrodisiac }\end{array}$ & $\begin{array}{l}\text { Oyedemi } \\
\text { et al. [17] }\end{array}$ \\
\hline $\begin{array}{c}\text { Pittosporum } \\
\text { viridiflorum } \\
\text { (Pittosporaceae) }\end{array}$ & Stem bark & $\begin{array}{c}\text { Back pain, fever, } \\
\text { stomach, chest, and } \\
\text { abdominal pains. } \\
\text { Inflammatory disorders }\end{array}$ & $\begin{array}{l}\text { Iwalewa } \\
\text { et al. [18] }\end{array}$ \\
\hline $\begin{array}{c}\text { Portulacaria afra } \\
\text { Jacq. } \\
\text { Portulacaceae }\end{array}$ & Leaves & $\begin{array}{c}\text { Rashes and chronic } \\
\text { sores }\end{array}$ & $\begin{array}{l}\text { De Wet } \\
\text { et al. [19] }\end{array}$ \\
\hline
\end{tabular}

Table 1: Previous reports on traditional uses of selected plants' species

leaf extracts of Portulacaria afra, are successfully used as traditional treatment agents for a variety of human ailments including obesity, inflammatory disorders, as well as skin infections, respectively (Table 1). Owing to the varieties of the secondary metabolites of plants, a single plant may be used for the treatment of various diseases in traditional medicine [16]. Currently, there are only limited studies on these three South African medicinal plants' species regarding some aspects of glucose metabolism. There is also limited information on the nature of the secondary plant metabolites in the extracts of these plants' species that may be responsible for this medicinal property. Furthermore, it is not known if there is a relationship between the antioxidant and/ or anti-inflammatory properties of the acetone extracts of these plants' species and glucose metabolism. The objective of this study was therefore to investigate the leaf acetone extracts of the $C$. dentata, $P$. afra, and P. viridiflorum plants' species for glucose utilization activity, anti-inflammatory, and antioxidant activities as well as to determine the total polyphenol and total flavonoid contents.

\section{Materials and Methods}

\section{Reagents and chemicals}

C2C12 mouse muscle myoblast (CRL-1772) and 3T3-L1 mouse pre-adipocytes fibroblast (CL-173) were purchased from American Type Culture Collection (ATCC) (Manassas, VA). Moreover, Trypan blue (Fluka), dimethyl sulfoxide (DMSO), acetone, methanol, and Whatman No. 1 filter paper were purchased from Merck (South Africa). All the other chemicals were purchased from Sigma (South Africa). The absorbance measurements were read using an Epoch micro plate reader (BioTek).

\section{Plant material}

The leaves of C. dentata, P. afra, and P. viridiflorum were collected from the SANBI Pretoria National botanical garden, and voucher specimens were deposited to the Department of Biology, Sefako Makgatho Health Sciences. The leaves were separated from the stems and dried at room temperature. The dried plant materials were milled to a fine powder in a Kenwood dry mill blender and stored at room temperature, in closed glass bottles in the dark, until extracted.

\section{Preparation of extracts}

The powdered plant material $(2 \mathrm{~g})$ was individually extracted with $20 \mathrm{ml}$ of acetone (technical grade - Merck) in polyester centrifuge tubes using a platform shaker (Labotec model 20.2 shaking machine) at room temperature for $30 \mathrm{~min}$ [20]. The extracts were centrifuged in a Rotofix $32 \mathrm{~A}$ Hettich centrifuge, and the clear supernatant was filtered through
Whatman No. 1 filter paper. This procedure was repeated three times on the same plant material with fresh solvent to ensure that all possible compounds were exhaustively extracted. The filtered extracts of each species were combined into pre-weighed glass vials, and the solvent was left to evaporate at room temperature under a stream of cold air. The extracts obtained were used for the subsequent assays.

\section{Phytochemical Screening}

\section{Total polyphenol content}

The total polyphenol content of the extracts was determined using the 96-well plate method adapted from Zhang et al. [21]. The extracts $(20 \mu \mathrm{l})$ were aliquot into the wells of a 96-well plate to which $100 \mu \mathrm{l}$ of $20 \%$ Folin-Ciocalteu reagent and $80 \mu \mathrm{l}$ of $7.5 \% \mathrm{Na}_{2} \mathrm{CO}_{3}$ solution were added. The final mixture was shaken and incubated for $60 \mathrm{~min}$ in the dark at room temperature, and the absorbance was measured at $760 \mathrm{~nm}$. The total phenolic content was calculated from the linear regression curve of Gallic acid, and the results are expressed as mg Gallic acid equivalent (GAE) per g of crude extract.

\section{Total flavonoid content}

The total flavonoid content of the extracts was determined using the 96-well plate method, adapted from Yadav and Agarwala [22]. The extracts $(100 \mu \mathrm{l})$ were dispensed into the wells of a 96-well plate, and $100 \mu \mathrm{l}$ of $2 \%$ aluminum chloride was added. The final mixture was shaken, incubated for $15 \mathrm{~min}$, and the absorbance was read at $430 \mathrm{~nm}$ in a microplate reader. A yellow color indicated the presence of flavonoids. The total flavonoid content was calculated from the linear regression curve of quercetin, and results are expressed as mg quercetin equivalent (QE) per g of crude extract.

\section{Antioxidant Activity}

\section{2,2-Diphenyl-1-picrylhydrazyl (DPPH) radical scavenging assay}

The DPPH radical-scavenging activity of the extracts was determined in a 96-well plate, using the modified methods of BrandWilliams et al. [23] and Fukumoto and Mazza [24]. To the extracts $(50 \mu \mathrm{l})$ in eight serial dilutions and the positive control in serial dilution $(8-250 \mu \mathrm{g} / \mathrm{ml}), 200 \mu \mathrm{l}$ of DPPH $(25 \mu \mathrm{g} / \mathrm{ml})$ was added. The DPPH solution was prepared daily and stored in an amber bottle. The change in absorbance at $517 \mathrm{~nm}$ was measured after 30 min incubation in the dark, with a microplate reader. Ascorbic acid and Trolox were used as positive controls, and extract without DPPH as blank. The results are expressed as percentage reduction of the initial DPPH absorption. The concentration, of extract leading to $50 \%$ reduction of $\mathrm{DPPH}\left(\mathrm{IC}_{50}\right)$, was determined.

\section{Anti-inflammatory Activity}

\section{Inhibition of 5-lipoxygenase assay}

The anti-inflammatory activity of the extracts was determined by the method of Baylac and Racine [25]. Briefly, extracts $(20 \mu \mathrm{l})$ or positive control in serial dilutions were added to the wells of a 96-well plate. To this, $50 \mu \mathrm{l}$ of the 5 -lipoxygenase enzyme ( 400 units $/ \mathrm{ml}$ cold $2 \mathrm{M}$ borate buffer, $\mathrm{pH}$ 6.9) was added and incubated at room temperature for $5 \mathrm{~min}$. Thereafter, $50 \mu \mathrm{l}$ substrate solutions $(10 \mu \mathrm{l}$ linoleic acid in $2 \mathrm{M}$ borate buffer, $\mathrm{pH}$ 6.9) and distilled water or quercetin were added to start the reaction and incubated for another $5 \mathrm{~min}$ at room temperature. After this, the absorbance was taken at $234 \mathrm{~nm}$. The percentage enzyme 
Citation: Olaokun OO, Mkolo NM, Mogale MA, King PH (2017) Phytochemical Screening, Antioxidant, Anti-inflammatory and Glucose Utilization Activities of Three South African Plants Used Traditionally to Treat Diseases. Biol Med (Aligarh) 9: 412. doi: 10.4172/0974-8369.1000412

Page 3 of 7

inhibition of extract compared with the control sample was calculated using the equation given below. The results are expressed as $\mathrm{IC}_{50}$, that is, the concentration of the extracts and controls that resulted in $50 \%$ 5-lipoxygenase inhibition.

$$
\begin{gathered}
\text { \% Inhibition }=100 \times\left(\frac{\Delta \mathrm{A}_{\text {Control }}-\Delta \mathrm{A}_{\text {Sample }}}{\Delta \mathrm{A}_{\text {Control }}}\right) \\
\Delta \mathrm{A}_{\text {Control }}=\mathrm{A}_{\text {Test }}-\mathrm{A}_{\text {Blank }} \\
\Delta \mathrm{A}_{\text {Sample }}=\mathrm{A}_{\text {Test }}-\mathrm{A}_{\text {Blank }}
\end{gathered}
$$

\section{Glucose Utilization Activity}

\section{C2C12 muscle cells glucose utilization}

C2C12 muscle myoblast were differentiated to myotubules by the method of Drira and Sakamoto [26] and glucose utilization assay was performed by the method of Olaokun et al. [27]. Briefly, the previously cultured C2C12 cells in Dulbecco's Modified Eagle's Medium (DMEM) medium supplemented with $10 \%$ foetal bovine serum (FBS) and $4 \mathrm{mM}$ glutamine at approximately $70 \%$ confluence were seeded $(25,000 \mathrm{cells} / \mathrm{ml})$ into the 96-well microplates. The cells were grown to confluence in the plates, and the medium was replaced with differentiating medium (DMEM supplemented with $2 \%$ horse serum and $4 \mathrm{mM}$ glutamine) and incubated at $37^{\circ} \mathrm{C}$ in a $\mathrm{CO}_{2}$ incubator. After 6 days, the medium was removed and replaced with $100 \mu \mathrm{l}$ of DMEM supplemented with $0.25 \%$ BSA, containing plant extracts at different concentrations $(31.25,62.5$, $125,250$, and $500 \mu \mathrm{g} / \mathrm{ml})$. Insulin $(1 \mu \mathrm{M})$ served as the positive control, and $0.5 \%$ DMSO served as the solvent control. After a $1 \mathrm{~h}$ incubation, the glucose concentration in the medium was determined by the glucose oxidase method (Sigma GAGO 20 test kit), according to instructions.

\section{T3-L1 adipocytes glucose utilization}

3T3-L1 pre-adipocytes were differentiated to adipocytes by the method of Ono et al. [28] and glucose utilization assay was determined by the previously described method [27]. Briefly, the previously cultured 3T3-L1 pre-adipocytes in DMEM culture medium supplemented with $10 \%$ bovine calf serum (BCS) and $4 \mathrm{mM}$ glutamine at approximately $70 \%$ confluence were seeded $(30,000$ cells $/ \mathrm{ml})$ into 96 -well microplates. The cells were grown to confluence, and day 2 post-confluent 3T3-L1 pre-adipocytes (day 0 ) were incubated in differentiation medium (fresh DMEM supplemented with $10 \% \mathrm{FBS}, 5 \mu \mathrm{g} / \mathrm{ml}$ insulin, $0.5 \mathrm{mmol} / \mathrm{l}$ 3-isobutyl-1-methylxanthine and $10 \mu \mathrm{mol} / \mathrm{l}$ dexamethasone). After 2 days, the medium was removed and replaced with a post-differentiation medium (fresh DMEM containing $10 \%$ FBS and $5 \mu \mathrm{g} / \mathrm{ml}$ insulin), and the medium was changed every other day for an additional 7 days. The medium in each of the wells was removed and replaced with $100 \mu \mathrm{l}$ of DMEM supplemented with $0.25 \%$ BSA containing plant extracts at concentrations of $31.25,62.5,125,250$, and $500 \mu \mathrm{g} / \mathrm{ml}$. Insulin $(1 \mu \mathrm{M})$ served as the positive control, and the solvent control was $0.5 \%$ DMSO. All the cells were subsequently incubated for $1 \frac{1}{2} \mathrm{~h}$. The glucose concentration in the medium was determined by using the glucose oxidase method (Sigma GAGO 20 test kit), according to instructions.

\section{Statistical Analyses}

All experiments were performed in triplicate and repeated three times. The data are presented as the mean \pm standard error of mean
(SEM). The statistical analyses were performed by one-way analysis of variance (ANOVA) and considered to be significantly different at $p<0.05$. When the significance was found, the location of significance was determined by Bonferroni and Tukey HSD multiple comparison post hoc tests.

\section{Results}

\section{Phytochemical screening}

The total phenolic content of the acetone extracts of the three plants' species (C. dentata, $P$. afra, and $P$. viridiflorum) is presented in Table 2. The total phenolic content of the extract of $C$. dentata was the highest $(125.12 \pm 2.18 \mathrm{mg} / \mathrm{g}$ GAE) compared to the extract of $P$. viridiflorum with the lowest total phenolic content $(26.08 \pm 1.41$ $\mathrm{mg} / \mathrm{g}$ GAE). Similarly, the total flavonoid content of $C$. dentata extract was the highest $(27.69 \pm 4.98 \mathrm{mg} / \mathrm{g} \mathrm{QE}$ ) (Table 2), while the extract of P. viridiflorum exhibited the lowest total flavonoid content $(20.31 \pm 2.60$ $\mathrm{mg} / \mathrm{g} \mathrm{QE})$.

\section{Antioxidant activity}

The DPPH radical scavenging antioxidant activity of the extracts was less potent than those of the positive controls ascorbic acid and trolox (Table 2). Among the three plants, the extract of $P$. viridiflorum exhibited a stronger DPPH radical scavenging ability with an $\mathrm{IC}_{50}$ value of $12.94 \pm 1.09 \mu \mathrm{g} / \mathrm{ml}$ than the other plant extracts. The $P$. afra extract exhibited the weakest DPPH radical scavenging ability with an $\mathrm{IC}_{50}$ value of $32.05 \pm 3.89 \mu \mathrm{g} / \mathrm{ml}$. The positive controls ascorbic acid and trolox potently scavenged the DPPH radical with an $\mathrm{IC}_{50}$ value of $0.21 \pm 1.45$ and $0.47 \pm 1.38 \mu \mathrm{g} / \mathrm{ml}$, respectively.

\section{Anti-inflammatory activity}

The extract of $P$. viridiflorum was a stronger inhibitor of 5 -lipoxygenase activity than the other plants, but was less potent than the positive control (Table 2). The extract of $P$. viridiflorum inhibited 5-lipoxygenase activity with an $\mathrm{IC}_{50}$ value of $107.26 \pm 5.63 \mu \mathrm{g} / \mathrm{ml}$, while the extract of $P$. afra was the weakest inhibitor $(107.26 \pm 5.63 \mu \mathrm{g} / \mathrm{ml})$ of 5-lipoxygenase activity. The positive control quercetin inhibited 5-lipoxygenase activity with an $\mathrm{IC}_{50}$ value of $9.02 \pm 2.38 \mu \mathrm{g} / \mathrm{ml}$.

\section{Glucose utilization activity of C2C12 muscle cells}

The effect of the acetone extracts of the three plants' species

\begin{tabular}{|c|c|c|c|c|}
\hline $\begin{array}{l}\text { Plant } \\
\text { extracts }\end{array}$ & $\begin{array}{c}\text { Total } \\
\text { phenolic } \\
\text { content } \\
\text { (mg/g GAE) }\end{array}$ & $\begin{array}{c}\text { Total } \\
\text { flavonoid } \\
\text { content } \\
\text { (mg/gQE) }\end{array}$ & $\begin{array}{l}\text { Antioxidant } \\
\text { activity } \\
\text { (DPPH) } \\
\mathrm{IC}_{50}(\mu \mathrm{g} / \mathrm{ml})\end{array}$ & $\begin{array}{c}\text { LOX } \\
\text { inhibitory } \\
\text { activity IC } \\
(\mu \mathrm{g} / \mathrm{ml})\end{array}$ \\
\hline C. dentata & $125.12 \pm 2.18$ & $27.69 \pm 4.98$ & $22.57 \pm 3.49$ & $95.38 \pm 4.04$ \\
\hline P. afra & $63.06 \pm 1.67$ & $22.16 \pm 6.41$ & $32.05 \pm 3.89$ & $107.26 \pm 5.63$ \\
\hline $\begin{array}{c}P . \\
\text { viridiflorum }\end{array}$ & $26.08 \pm 1.41$ & $20.31 \pm 2.60$ & $12.94 \pm 1.09$ & $46.50 \pm 4.54$ \\
\hline Trolox & nd & nd & $0.47 \pm 1.38$ & nd \\
\hline $\begin{array}{l}\text { Ascorbic } \\
\text { acid }\end{array}$ & nd & nd & $0.21 \pm 1.45$ & nd \\
\hline Quercetin & nd & nd & nd & $9.02 \pm 2.38$ \\
\hline
\end{tabular}
(C. dentata, P. afra, and P. viridiflorum) on glucose utilization of $\mathrm{C} 2 \mathrm{C} 12$ myotubule is presented in Figure 1. All the extracts of the plants

Values are means of triplicate determinations performed three times $(n=9) \pm$ standard error; 5-LOX: 5-lipoxygenase; nd: not determined.

Table 2: Total phenolic content, total flavonoid content antioxidant, and 5-lipoxygenase inhibitory activity of acetone extracts of three plants' species 


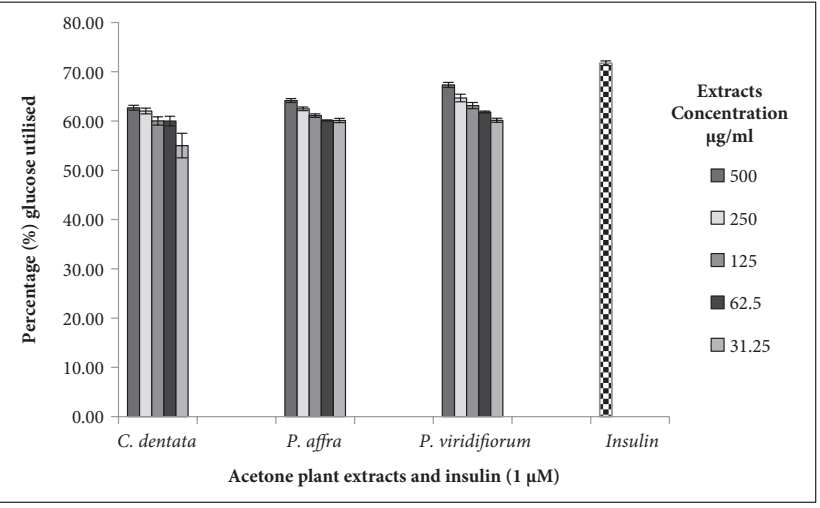

Figure 1: Glucose utilization in $\mathrm{C} 2 \mathrm{C} 12$ muscle cells (expressed as percentage of untreated control cells \pm standard error of mean, $n=9$ ) exposed to different concentrations of plants' extracts

enhanced the glucose utilization activity of the $\mathrm{C} 2 \mathrm{C} 12$ muscle cells in a dose-response manner. The extracts of $P$. viridiflorum enhanced the highest $(67.34 \pm 0.51 \%)$ glucose utilization activity of the muscle cells at the highest concentration $(500 \mu \mathrm{g} / \mathrm{ml})$ with no significant difference $(p<0.05)$ among the plants extracts. The glucose utilization activity of the $\mathrm{C} 2 \mathrm{C} 12$ muscle cells by the extract of $C$. dentata and $P$. afra was $62.69 \pm 0.50$ and $64.17 \pm 0.40 \%$, respectively, at the highest concentration of $500 \mu \mathrm{g} / \mathrm{ml}$. Insulin (positive control) at a concentration of $1 \mu \mathrm{M}$ enhanced $71.73 \pm 0.47 \%$ glucose utilization activity of the C2C12 muscle cells.

\section{Glucose utilization activity of 3T3-L1 adipocytes}

The effect of the acetone extracts of the three plants' species (C. dentata, $P$. afra, and $P$. viridiflorum) on glucose utilization of 3T3-L1 adipocytes is presented in Figure 2. All the extracts enhanced the glucose utilization activity of 3T3-L1 adipocytes with no significant difference $(p<0.05)$ among them. The extracts of C. dentata and P. viridiflorum, respectively, enhanced $63.72 \pm 0.48 \%$ and $63.15 \pm 0.68 \%$ glucose utilization activity of 3T3-Li adipocytes at the highest concentration of $500 \mu \mathrm{g} / \mathrm{ml}$. Insulin, the positive control, enhanced $70.45 \pm 0.22 \%$ glucose utilization activity of $3 \mathrm{~T} 3-\mathrm{L} 1$ adipocytes at the concentration of $1 \mu \mathrm{M}$.

\section{Discussion}

Medicinal plants are potential sources of new compounds for the control or treatment of diseases which, in turn, could be the sources of lead compounds for drug development [29]. The leaves of $C$. dentata, $P$. afra, and $P$. viridiflorum were used for this study, because they are a renewable source of materials for the production of plant medicines or herbal remedies. These leaves were crushed to powder to reduce the particle size and were extracted with acetone. This differed from the traditional practice where herbal remedies would be prepared with either water or alcohol [30]. Acetone, being a solvent of intermediate polarity, has the capacity to extract a greater variety of compounds. The larger the variety of compounds that is extracted by solvents, the broader will be the expected spectrum of biological activity and the biologically active compounds that should be extracted. Unfortunately, in systems where water and alcohol are the extraction solvents, mainly polar compounds will be extracted thus limiting the amount of active compounds obtainable from plants.

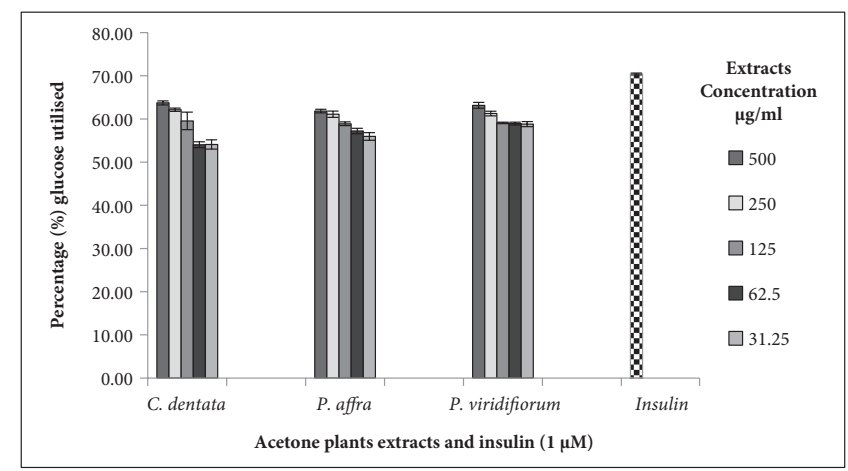

Figure 2: Glucose utilized in 3T3-L1 adipocytes (expressed as percentage of untreated control cells \pm standard error of mean, $n=9$ ) exposed to different concentrations of plants' extracts

Similar to the polar solvents (water and alcohol), acetone can extract polyphenols but with fewer compounds (sugars) that can interfere with bioassays, which measure glucose concentration [32,33]. Polyphenols are phytochemicals that are recognized for their potential health benefit. Studies indicate that the consumption of food and beverages rich in polyphenols are associated with significant reduced risks for a variety of non-communicable diseases and are considered to be an important component of the human diet [34]. The total polyphenol content of $C$. dentata $(125.12 \pm 2.18 \mathrm{mg} / \mathrm{g}$ GAE) acetone extract was the highest among the three plants investigated. The polyphenols are a large and heterogeneous group of phytochemicals in plants that comprise the groups of flavonoids and phenolic acids. The flavonoid group of compounds shares a common structure that consists of two aromatic rings ( $\mathrm{A}$ and $\mathrm{B}$ ), bound together by three carbon atoms that form an oxygenated heterocycle (ring C) [35]. They are widely distributed in plants and have been demonstrated to exhibit a variety of biological activities, including antioxidant, anti-inflammatory, and antidiabetic. The total flavonoid content of the selected plants' species evaluated as quercetin equivalent, resulted in C. dentata containing the highest $(27.69 \pm 4.98 \mathrm{mg} / \mathrm{g} \mathrm{QE})$ among the plants investigated. There is limited information on the quantitative phytochemical content of C. dentata. One study reported that $C$. dentata's hydroalcoholic extract contains a total polyphenol content of $14.86 \pm 0.05 \mathrm{mg} / \mathrm{g}$ tannic acid equivalent and total flavonoid content of $13.64 \pm 0.03 \mathrm{mg} / \mathrm{g} \mathrm{QE} \mathrm{[17].}$ The lower total polyphenol and flavonoid content may be due, in part, to the solvent of extract [31].

Considerable evidence abound indicate that increased oxidative damage is associated with/and may contribute to the development of degenerative diseases and age-related diseases including diabetes [36]. Plant antioxidants may limit this damage by acting directly on reactive oxygen species or by stimulating endogenous defense system [37]. Polyphenols have been attributed to possess disease protective effects owing to their antioxidant ability [36]. Coupled with this, the phenolic groups in the polyphenols can accept electrons to form relatively stable phenoxyl radicals, thereby disrupting chain oxidation reactions in cellular components [37]. The antioxidant potency of C. dentata, P. afra, and $P$. viridiflorum's extracts was evaluated by the ability to scavenge $\mathrm{DPPH}$ radicals, and the extract of $P$. viridiflorum $(12.94 \pm 1.09 \mu \mathrm{g} /$ $\mathrm{ml}$ ) was the most potent scavenger. There was no correlation between the phytochemical content and antioxidant activity of the extracts. The conflicting results have been reported by other authors. While 
some authors found correlation between the polyphenol content and antioxidant activity, others found no relationship. However, studies have shown that high polyphenol content does not always translate to high antioxidant activity [38]. Moreover, the antioxidant efficiency of the polyphenol depends, in part, on the position and extent of hydroxylation and conjugation [39].

Polyphenolic extracts with high antioxidant activity are speculated to exhibit potent anti-inflammatory activity [40]. The reason may be attributed to ROS being an underlining factor inducing both oxidative stress and inflammatory cytokines [41]. The anti-inflammatory activity of the acetone extracts of the plants was evaluated by the inhibition of 5-lipoxygenase activity. These are lipid peroxidizing enzymes involved in the biosynthesis of inflammatory lipid mediators such as leukotrienes and prostaglandins. They catalyze the addition of molecular oxygen into poly-unsaturated fatty acids such as arachidonic and linoleic acids [42]. In this study, no correlation was found between phytochemical content and anti-inflammatory activity of the extracts. The potent anti-inflammatory ability by inhibition of 5-lipoxygenase activity is enhanced when polyphenols possess an 11-keto group and a hydrophilic function in the pentacyclic ring system [43]. Despite the extract of $P$. viridiflorum having the lowest total polyphenol content, the extract exhibited the strongest anti-inflammatory activity among the plants' extracts evaluated. In addition, there seems to be a relationship between antioxidant and anti-inflammatory activity of the extract of P. viridiflorum. The implication of this is that polyphenolic compounds alone may likely not be responsible for the superior antioxidant and anti-inflammatory activity of the extract of $P$. viridiflorum. In addition, according to the report of Kamatou et al. [43], the extracts of these plants may possess moderate anti-inflammatory activity. However, it is important to note that the moderate anti-inflammatory activity of these plants does not imply that the extracts may not possess stronger anti-inflammatory activity, if evaluated in other anti-inflammatory bioassays.

With glucose being the main energy fuel requirement of the body, it has to be transported from the blood across the cell membrane into the cellular cytoplasm for it to be utilized by the cells. However, the membrane of cells is impermeable to glucose, and thus the cell is reliant on trans-membrane proteins transporters (GLUT) for diffusion into the cell [44]. The impairment in the regulation of blood glucose level may lead to an imbalance that may lead to hyperglycemia thus Type 2 diabetes necessitating proper management [41]. Polyphenols are plant chemicals that possess hypoglycemic potentials [45]. One mechanism through which this group of chemical modulate glucose metabolism is to stimulate the muscle and fat cells to increase their glucose utilization activities. We investigated the effect of C. dentata, P. afra, and $P$. viridiflorum extracts on the glucose utilization activities of $\mathrm{C} 2 \mathrm{C} 12$ muscle cells and 3T3-L1 adipocytes. The result revealed that the acetone extracts of the selected plants in dose responsive manner enhanced the glucose utilization activities of the muscle and fat cells to the same extent. This indicates that the extracts of the plants' species possessed the potential to overcome insulin resistance in the cells. Insulin resistance is present when the biological effect of insulin is not sufficiently potent to enhance the glucose uptake of the muscle cells and adipocytes [46]. No relationship was found between the phytochemical content and the glucose utilization activity of the plant extracts. However, to some extent, for the extract of $C$. dentata, there is a possible relationship between the phytochemical content and the glucose utilization activity of the 3T3-L1 adipocytes. Some studies reported that, for some plant extracts at least, a positive correlation exists between antidiabetic activity and flavonoid content $[47,48]$. There is also a possibility that the compounds facilitating the glucose utilization activity of the $\mathrm{C} 2 \mathrm{C} 12$ muscle cells may be different from that stimulating the glucose utilization activity of the 3T3-L1 adipocytes. Although the mechanism by which the selected plants' extracts enhanced glucose utilization activities of the cells was not investigated, the limiting step of insulin stimulated the glucose uptake of muscle and fat is the translocation of GLUT4 transporters to the plasma membrane [49]. Studies showed that polyphenols are able to enhance the glucose utilization activity by either acting as insulin mimetic [50,51] or without affecting the insulin receptor autophosphorylation and/or transporter translocation to the plasma membrane [45]. One of these mechanisms might have been the action mode by which the plants' extracts enhanced the glucose utilization activities of the cells. This study was the first to demonstrate that the extracts $C$. dentata, $P$. afra, and $P$. viridiflorum have the potential to enhance the glucose utilization activities, thus attenuating hyperglycemia. As the extract of $C$. dentata is used traditionally to treat obesity, the result of this study further corroborated that it is used in the treatment of obesity-related disorders such as diabetes. Obesity is one of the factors provoking insulin resistance in the responsive cells. With the polyphenolic compounds of $C$. dentata enhancing superior glucose utilization activity of 3T3-L1 adipocyte, the plant would have been one potential source of therapeutic agent for diabetes. Unfortunately, no further investigation can be conducted as this plant is a threatened species [52]. Similarly, the extract of $P$. viridiflorum is used in traditional medicine to treat inflammatory conditions. Inflammation, especially activated by obesity, is demonstrated to be one of the causes of insulin resistance in a diabetic state. The extract of $P$. viridiflorum contained phytochemicals possessing anti-inflammatory activity and enhanced the superior glucose utilization activity of $\mathrm{C} 2 \mathrm{C} 12$ muscle cells. Therefore, the extract of $P$. viridiflorum can be further investigated as is a potential source for hypoglycemia remedies and compounds.

\section{Conclusion}

C. dentata, P. afra, and P. viridiflorum are medicinal plants used traditionally in South Africa to treat diseases. This study investigated the effects of the polyphenols and flavonoids of acetone extracts of these plants' species on glucose utilization activity of muscle and fat cells, anti-inflammatory, and antioxidant activity. All the extracts of the plants contained various amounts of polyphenols and flavonoids. In general, there is no relationship between the phytochemical contents of the plants' species and the antioxidant, anti-inflammatory, and glucose utilization activities. For the extract of $C$. dentata, the polyphenols and particularly flavonoids may likely be responsible for the superior glucose utilization activity of 3T3-L1 adipocytes. For the extract of $P$. viridiflorum, other compounds that are not polyphenols are likely to be responsible for the superior anti-inflammatory and antioxidant activities as well as the glucose utilization activity of $\mathrm{C} 2 \mathrm{C} 12$ muscle cells. This study demonstrated the possibility of plants used frequently to treat diseases as potential therapeutic sources for diabetes.

\section{Competing Interests}

The authors declare that they have no competing interests.

\section{Acknowledgments}

Sefako Makgatho Health Sciences University provided the DHET Research Development Grant (RDG) for this study, while the facility of the Phytomedicine Programme laboratory at the University of Pretoria was used for part of the study. 
Citation: Olaokun OO, Mkolo NM, Mogale MA, King PH (2017) Phytochemical Screening, Antioxidant, Anti-inflammatory and Glucose Utilization Activities of Three South African Plants Used Traditionally to Treat Diseases. Biol Med (Aligarh) 9: 412. doi: 10.4172/0974-8369.1000412

\section{References}

1. World Health Organization (2002) Traditional medicine strategy 2002-2005 Geneva: World Health Organisation Publications, pp. 1-16.

2. World Health Organization (1980) WHO Expert committee on diabetes mellitus second report. WHO Technical Report Series 646. Geneva: World Health Organization.

3. Marles R, Farnsworth N (1994) Plants as sources of anti-diabetic agents. In Wagner H, Farnsworth NR, eds. Economic and Medicinal Plant Research, vol. 6. London: Academic Press, pp. 149-187.

4. World Health Organization (1996) WHO Guideline for the Assessment of Herbal Medicines. WHO Expert Committee on specification for pharmaceutical preparation. Technical Report series no. 863, Geneva.

5. Mahomed IM, Ojewole JA (2006) Anti-convulsant activity of harpagophytum procumbens DC [pedaliaceae] secondary root aqueous extract in mice. Brain Res Bull 69(1): 57-62.

6. Mulholland DA (2005) The future of ethnopharmacology a South African perspective. J Ethnopharmacol 100: 124-126.

7. Katerere DR, Eloff JN (2005) 11 management of diabetes in African traditional medicine. In: Saiki I, Soumyanath A, eds. Traditional Medicines for Modern Times: Anti-diabetic Plants. London: CRC Taylor and Francis Press, p. 203.

8. Borokini TI, Omotayo FO (2012) Phytochemical and ethnobotanical study of some selected medicinal plants from Nigeria. J Med Plants Res 6(7): 11061118 .

9. Meydani M, Hasan ST (2010) Dietary polyphenols and obesity. Nutrients 2(7): 737-751.

10. Yao Y, Sang W, Zhou M Ren G (2009) Antioxidant and $\alpha$-glucosidase inhibitory activity of colored grains in China. J Agric Food Chem 58(2): 770-774.

11. Hanhineva K, Torronen R, Bondia-Pons I, Pekkinen J, Kolehmainen M, et al (2010) Impact of dietary polyphenols on carbohydrate metabolism. Int J Mol Sci 11(4): 1365-1402.

12. Hossain P, Kawar B, El Nahas M (2007) Obesity and diabetes in the developing world-a growing challenge. N Engl J Med 356(3): 213-215.

13. Kanamoto Y, Yamashita Y, Nanba F, Yoshida T, Tsuda T, et al. (2011) A black soybean seed coat extract prevents obesity and glucose intolerance by upregulating uncoupling proteins and down-regulating inflammatory cytokines in high-fat diet-fed mice. J Agric Food Chem 59(16): 8985-8993.

14. Hu FB, Meigs JB, Li TY, Rifai N Manson JE (2004) Inflammatory markers and risk of developing type 2 diabetes in women. Diabetes 53: 693-700.

15. Johansen JS, Harris AK, Rychly DJ, Ergul A (2005) Oxidative stress and the use of antioxidants in diabetes: linking basic science to clinical practice. Cardiovasc Diabetol 4(1): 5.

16. Doughari JH, Ndakidemi PA, Human IS, Benade S (2011) Curtisia dentata: ethnopharmacological application. J Med Plants Res 5(9): 1606-1612.

17. Oyedemi SO, Oyedemi BO, Arowosegbe S, Afolayan AJ (2012) Phytochemicals analysis and medicinal potentials of hydroalcoholic extract from Curtisia dentata (Burm. f) CA Sm stem bark. Int J Mol Sci 13(5): 6189-6203.

18. Iwalewa EO, McGaw LJ, Naidoo V, Eloff JN (2007) Inflammation: the foundation of diseases and disorders. A review of phytomedicines of South African origin used to treat pain and inflammatory conditions. Afr J Biotechnol 6(25): 28682885

19. De Wet H, Nciki S Van Vuuren SF (2013) Medicinal plants used for the treatment of various skin disorders by rural community of northern Maputaland, South Africa. J Ethnobiol Ethnomed 9: 51

20. Eloff JN (1998) A sensitive and quick microplate method to determine the minimal inhibitory concentration of plants extracts for bacteria. Planta Med 64 711-713

21. Zhang Q, Zhang J, Shen J, Silva A, Dennis DA, et al. (2006) A simple 96 well microplate method for estimation of total polyphenolic content in seaweeds. $J$ Appl Phycol 18: 445-450.

22. Yadav RNS, Agarwala M (2011) Phytochemical analysis of some medicinal plants. J Phytol 3(12): 10-14

23. Brand-Williams W, Cuveleir ME, Berset C (1995) Use of a free radical method to evaluate antioxidant activity. LWT Food Sci Technol 28(1): 25-30
24. Fukumoto LR, Mazza G (2000) Assessing antioxidant and prooxidant activities of phenolic compounds. J Agric Food Chem 48(8): 3597-3604.

25. Baylac S, Racine P (2003) Inhibition of 5-lipoxygenase by essential oils and other natural fragrant extracts. Int J Aromather 13: 138-142.

26. Drira R, Kazuichi Sakamoto K (2013) Modulation of adipogenesis, lipolysis and glucose consumption in 3T3-L1 adipocytes and $\mathrm{C} 2 \mathrm{C} 12$ myotubes by hydroxytyrosol acetate: a comparative study. Biochem Biophys Res Commun 440: 576-581.

27. Olaokun OO, McGaw LJ, van Rensburg IJ, Eloff JN, Naidoo V (2016) Antidiabetic activity of the ethyl acetate fraction of Ficus lutea (Moraceae) leaf extract: comparison of an in vitro assay with an in vivo obese mouse model. BMC Complemen Altern Med 16(1): 1

28. Ono Y, Hattori E, Fukaya Y, Imai S, Ohizumi Y (2006) Anti-obesity effect of Nelumbo nucifera leaves extract in mice and rats. J Ethnopharmacol 106: 238 244

29. Matu EN, Van Staden J (2003) Antibacterial and anti-inflammatory activities of some plants used for medicinal purposes in Kenya. J Ethnopharmacol 87(1) 35-41.

30. Kelmanson JE, Jäger AK, van Staden J (2000) Zulu medicinal plants with antibacterial activity. J Ethnopharmacol 69(3): 241-246.

31. Eloff JN (1998) Conservation of medicinal plants: selecting medicinal plant for research and gene banking. Monographs in Systematic Botany from the Missouri Garden 71, 209-222. In: Adams RP, Adams JE, eds. Conservation of Plants Genes III: Conservation and Utilisation of African Plants. St. Louis, MO: Missouri Botanical Garden Press.

32. Ali H, Houghton PJ, Soumyanath A (2006) $\alpha$-Amylase inhibitory activity of some Malaysian plants used to treat diabetes; with particular reference to Phyllanthus amarus. J Ethnopharmacol 107(3): 449-455.

33. Shinde J, Taldone T, Barletta M, Kunaparaju N, Hu B, et al. (2008) $\alpha$-Glucosidase inhibitory activity of Syzygium cumini (Linn.) Skeels seed kernel in vitro and in Goto-Kakizaki (GK) rats. Carbohydr Res 343(7): 1278-1281.

34. Mai TT, Thu NN, Tien PG, Van Chuyen N (2007) Alpha-glucosidase inhibitory and antioxidant activities of Vietnamese edible plants and their relationships with polyphenol contents. J Nutr Sci Vitaminol 53(3): 267-276.

35. Manach C, Scalbert A, Morand C, Remesy C, Jimenez L (2004) Polyphenols: food sources and bioavailability. Am J Clin Nutr 79(5): 727-747.

36. Halliwell B (2008) Are polyphenols antioxidants or pro-oxidants? What do we learn from cell culture and in vivo studies? Arch Biochem Biophys 476(2): $107-112$

37. Scalbert A, Manach C, Morand C, Remesy C, Jimenez L (2005) Dietary polyphenols and the prevention of diseases. Crit Rev Food Sci Nutr 45(4): 287 306

38. Olaokun OO, McGaw LJ, Eloff JN, Naidoo V (2013) Evaluation of the inhibition of carbohydrate hydrolysing enzymes, antioxidant activity and polyphenolic content of extracts of ten African Ficus species (Moraceae) used traditionally to treat diabetes. BMC Complement Altern Med 13(1): 1.

39. Pulido R, Bravo L, Saura-Calixto F (2000) Antioxidant activity of dietary polyphenols as determined by a modified ferric reducing/antioxidant powe assay. J Agric Food Chem 48(8): 3396-3402.

40. Sala A, Recio MC, Schinella GR, Mánez S, Giner RM, et al. (2003) Assessment of the anti-inflammatory activity and free radical scavenger activity of tiliroside. Eur J Pharmacol 461: 53-61.

41. Tiwari AK, Rao JM (2002) Diabetesmellitus and multiple therapeutic approaches of phytochemicals: present status and future prospects. Curr Sci 83: $30-38$

42. Porta H, Rocha-Sosa M (2002) Plant lipoxygenases. Physiological and molecular features. Plant Physiol 130(1): 15-21.

43. Kamatou GP, Viljoen AM, Steenkamp P (2010) Antioxidant, anti-inflammatory activities and HPLC analysis of South African Salvia species. Food Chem 119(2): 684-688.

44. Klip AM, Tsakiridis TH, Marette AN, Ortiz PA (1994) Regulation of expression of glucose transporters by glucose: a review of studies in vivo and in cell cultures. FASEB J 8(1): 43-53. 
Citation: Olaokun OO, Mkolo NM, Mogale MA, King PH (2017) Phytochemical Screening, Antioxidant, Anti-inflammatory and Glucose Utilization Activities of Three South African Plants Used Traditionally to Treat Diseases. Biol Med (Aligarh) 9: 412. doi: 10.4172/0974-8369.1000412

Page 7 of 7

45. Cazarolli LH, Zanatta L, Alberton EH, Figueiredo MS, Folador $\mathrm{P}$, et al. (2008) Flavonoids: cellular and molecular mechanism of action in glucose homeostasis. Mini Rev Med Chem 8(10): 1032-1038.

46. Stumvoll M, Goldstein BJ, van Haeften TW (2005) Type 2 diabetes: principles of pathogenesis and therapy. Lancet 365(9467): 1333-1346.

47. Sezik E, Aslan M, Yesilada E, Ito S (2005) Hypoglycaemic activity of Gentiana olivieri and isolation of the active constituent through bioassay-directed fractionation techniques. Life Sci 76(11): 1223-1238.

48. Aslan M, Deliorman Orhan D, Orhan N, Sezik E, Yesilada E (2007) In vivo antidiabetic and antioxidant potential of Helichrysum plicatum ssp. plicatum capitulums in streptozotocin-induced-diabetic rats. J Ethnopharmacol 109(1): 54-59.
49. Saltiel AR, Kahn CR (2001) Insulin signalling and the regulation of glucose and lipid metabolism. Nature 414(6865): 799-806.

50. Cao H, Graves DJ, Anderson RA (2010) Cinnamon extract regulates glucose transporter and insulin-signaling gene expression in mouse adipocytes. Phytomedicine 17(13): 1027-1032.

51. Jorge AP, Horst H, de Sousa E, Pizzolatti MG, Silva FRMB (2004) Insulinomimetic effects of kaempferitrin on glycaemia and on $14 \mathrm{C}$-glucose uptake in rat soleus muscle. Chem Biol Interact 149(2): 89-96.

52. Shai LJ, McGaw LJ, Eloff JN (2009) Extracts of the leaves and twigs of the threatened tree Curtisia dentata (Cornaceae) are more active against Candida albicans and other microorganisms than the stem bark extract. S Afr J Bot 75(2): 363-366. 